\title{
مهارات التفكير الجانبى فى الرياضيات المناسبة لتلاميذ الصف الثاني بالمرحلة الاعدادية
}

$$
\text { إعداد }
$$

$$
\text { أ.د / حفنى إسماعيل محمد }
$$

أستاذ المناهج وطرق تدريس الرياضيات كلية التربية بقتا - جامعة جنوب الو ادى الدي

أ / إسلام حسن إبراهيه يوسف

باحث ماجستير - قسم المناهج وطرق التدريس كلية التربية بقنا - جامعة جنوب الو الديز الى
أ. داد/ ن نادىمال عزيز

أستاذ المناهج وطرق تحريس الرياضيات

كلية التربية - جامعة أسوان

\section{د دممد حسن عبدالشـافي}

مدرس المناهج وطرق تدريس الرياضيات

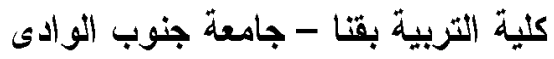


مهارات التفكير الجانبى فى الرياضيات المناسبة لتلاميذ الصف الثاني بالمرحلة الاعدادية

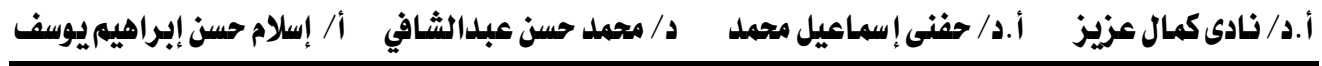
مهارات التفكير الجانبى فى الريـاضيات المناسبة لتلاميذ الصف الثاني بـالمر حلة الاعدادية

\section{إعداد}

\section{أ. د / حفنى إسماعيل محمد}

أستاذ المناهج وطرق تدريس الرياضيات

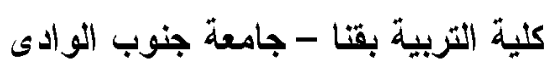

\section{أ إسلام حسن إبراهيم يوسف}

باحث ماجستير - قسم المناهج وطرق التدريس

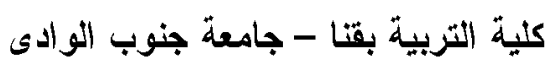

\section{أ.د د نادى كمال عزيز}

أستاذ المناهج وطرق تدريس الرياضيات

كلية التربية - جامعة أسوان ونان

د/ محمد حسن عبدالشافي

مدرس المناهج وطرق تثريس الزياضيات

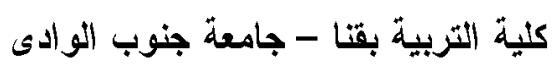

\section{المستخلص : (المن}

هدف البحث إلى تحديد المفاهيم ، والتعميمات ، والمهارات المتضمنة بوحدتي العلاقة بين متغيرين ومنوسطات المتلث بكتاب الرياضيات الصف الثانى الإعدادي ، كما هدف إلى تحديد

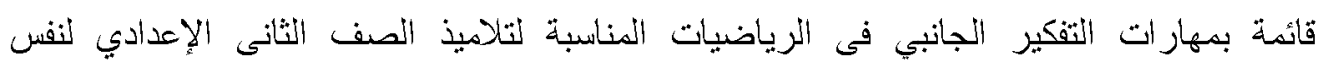

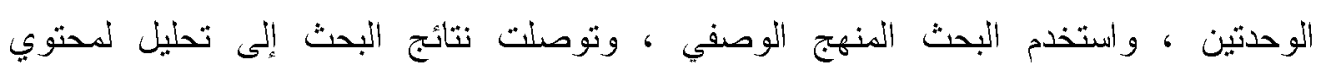

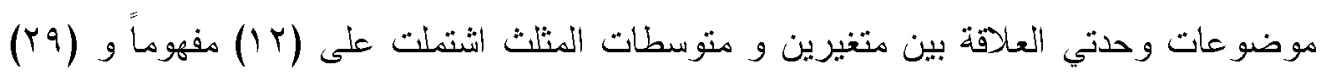

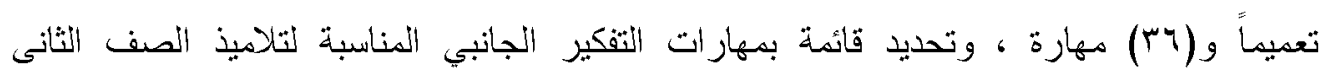

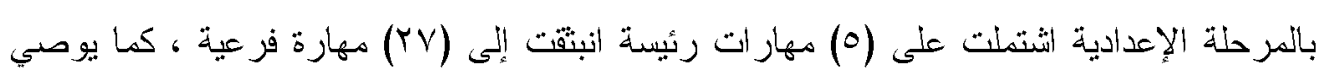

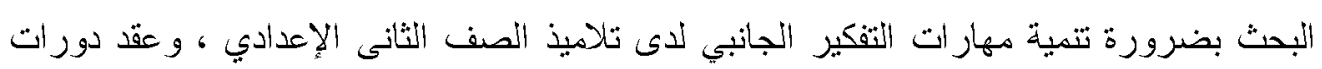

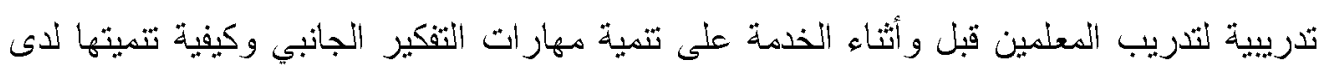
تلاميذهم وتطوير مناهج الرياضيات بالمرحلة الاعدادية بما بسمح للمعلم و التلميذ من استخدام

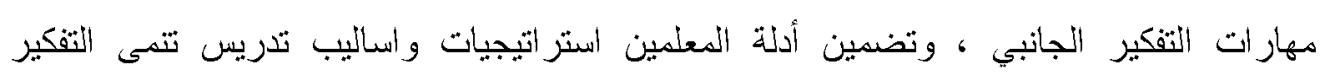
الجانبي ومرتبطة بما يدرسد التتلاميذ.

الكلمات المفتاحية : تحليل المحتوى ، التقكير الجانبي . 


\section{مهارات التفكير الجانبى في الرياضيات المناسبة لتلاميذا الصف الثاني بالمرحلة الاعدادية

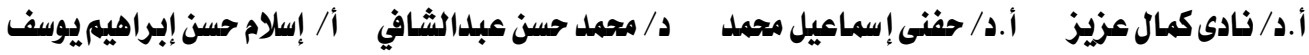 \\ Lateral Thinking Skills in Mathematics of $2^{\text {nd }}$ Stage of \\ Preparatory School Pupils}

\section{Prepared by}

Prof.Dr.:Nady Kamal Azez

Professor of Curriculum and Methods

of Teaching Mathematics

Faculty of Education

Aswan University

Dr.:Mohamed Hassan Abdelsha

Curriculum teacher and methods

of teaching mathematics

Faculty of Education of Qana

South Valley University
Prof.Dr.: Hofny Ismael Mohamed

Professor of Curriculum and Methods

of Teaching Mathematics

Faculty of Education of Qanal

South Valley University

Islam Hassan Ibrahem Yousef

Master's Researcher - Department

Curriculum and Teaching Methods

Faculty of Education of Qana

South Valley University

\section{Abstract:}

The aim of the research is to identify the concepts, generalizations, and skills contained in the Relation between two Variables and Medians of a triangle units in the mathematics book for the eighth grade, and to identify a list of lateral thinking skills for the same units. The researcher used the descriptive curriculum. The results of the search resulted for analysis of the content of the subjects of the Relation between two Variables and Medians of a triangle units, and the spaces included (12) concept, (29) generalization, and (36) skill and identification of a list of lateral thinking skills suitable for $2^{\text {nd }}$ preparatory stage that included (5) the skill of the president that emerged to (27) sub-skill. The research also recommends that attention should be given to developing the lateral thinking skills of pupils, and that training courses should be held to train teachers before and during the service to develop of lateral thinking skills and how they are developed by their pupils.

Key Words: Content analysis - Lateral thinking. 


\section{ههارات التفكير الجانبى فى الرياضيات المناسبة لتلاميذ الصف الثاني بـالمرحلة الاعدادية}

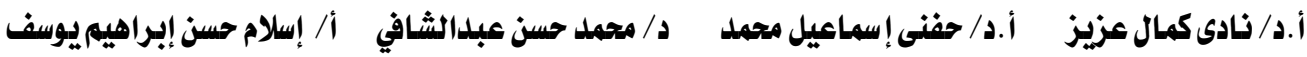

مقدمة : مقام

لقد ميز الله الإنسان عن سائر المخلوقات بالعقل؛ ليستخدمه فيما خُلقَ من أجله، ومن نعم الله على الإنسان أن جعل العقول متفاوتة في قدراتها، فهنا"كى من مَن الله عليه بقدرة عقلية كبيرة، و هناكت من امتحذه الله بقدرة عقلية محدودة، وبين هذا وذالك آخرون متفاوتون فيما يمتلكون من ملكات، فاله أمر كل إنسان أن بستخدم عقله في تدبير أمور حياته، وهذا ما يدفع المجتمع إلى التقدم و التطور، فثروات الثشعوب لا تقاس بما يمتلكه الوطن من معادن، إنما بما بمتلكه من عقول أبنائه.

ويلعب التفكير دوراً جوهريا في حياة الإنسان؛ لذا برز الاهتمام بتتمية التفكير بأثكاله المتتوعة كمطلب ملح من أجل بناء جيل قادر على مواكبة العصر الأي نعيشه والتقدم والانفجار المعرفي الهائل، ويعد التفكير هو الأداة التي يو اجه بها الإنسان منغيرات العصر، كما أنه يحتل دوراً مهماً في عملية التعليم والتعلم، فلم بعد الهدف من العملية التعليمية فاصراً على إكساب المتعمين المعارف والحقائق و المهارات الأساسية، بل يجب أن يتعدى هذا الهذف إلى تتمية قدرات المتعلمين على التفكير بأنو اعه المختلفة.

وتعد الرياضيات ميداناً خصباً للتدريب على أساليب التفكير السليدة؛ حيث إن من أهداف تدريس الزياضيات في دول العالم هو تتمية مهار ات التفكير، وعلى مستوى الوطن العربي تهدف الزرياضيات إلى تتمية القدرة على الكثف، والابتكار، وتدريب المتعلم على علية التجريد و التعميه، وأن يكتبب المتعلم اتجاهات علمية في تفكيره لمواجهة المشكلات واختيار الحول المناسبة لها، ومهارات التفكير في مجال الرياضيات كهدف تربوي يمكن تحقيقه عن طريق التنديب و الممارسة

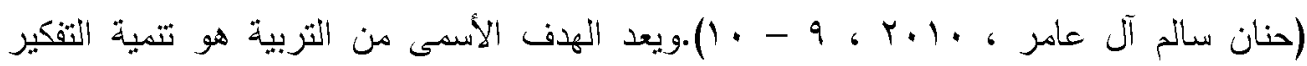




\section{مهارات التفكير الجانبى فى الرياضيات المناسبة لتلاميلذ الصف الثاني بـالمرحلة الاعلادية}

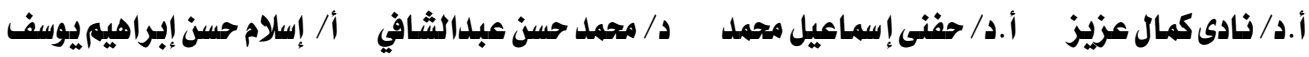

بجميع أُنكاله لدى كل متعلم؛ لذا يتعاظم دور المؤسسة التربوية في إعداد منعلمين قادرين على حل المشكلات الرياضية بطرق غير المتوقعة، ولديهم القدرة على التفكير في بدائل متتوعة ومتعددة

$$
\text { للمو اقف المتجددة (انشر اح محمد المشرفي ، 0. . ب ، } 19 \text { - . ب). }
$$

ويرجع ذلك إلى الإبداع في كل مجالات الحياة، وإلى دور المبدعين في تغيير وإعادة تثكيل العالم أو التو اقع، وتتافس الأول المتقدمة فيما بينها نتتجيع الإبداع ورعاية المبدعين، وعلى الرغم من ذلك فإن الجهود المبذولة في بعض الدول في هذا المجال لا تز ال قليلة ومحدودة (مدحت محمد

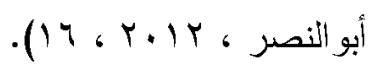

كما أن الاهتمام بتتمية الإبداع كقدرة عقلية أصبح ضرورة من الضروريات الملحة، التي تقع على عاتق المناهج الدر اسية؛ فلم بعد دور المدرسة قاصراً على نقل المعلومات والمعارف، بل أصبح مسؤولاً عن تدريب المتعلمين على التفكير الإبداعي، وتطوير قدر اتهم الإبداعية، كما أصبح دور المدرسة اليوم قائمًا على إعداد المتعلمين، بحيث يكونون قادرين على مواجهة النطورات الحياتية، وحل المشكلات التي تواجههم من خلال تطوير قدراتهم الإبداعية (مبارك مبارث أبومزيد $\cdot(0, r \cdot 1) \cdot$

و التفكير الجانبي شديد الارتباط بالإبداع؛ حيث يعد وصفاً لعملية فكرية مطولة تهنم بإبداع أفكار جديدة، ويعني أيضاً تجنب الففاهيم الخاصدة بالأفكار التي تجاوزها الزمان، ويتطلب هذا بالطبع

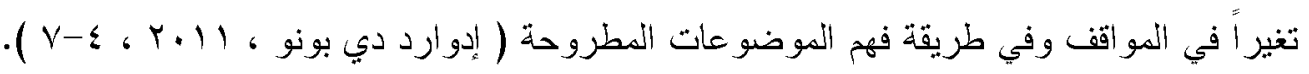

و التفكير الجانبي متعلق بالتفكير الإبداعي، لأنه مرتبط بالأفكار الجديدة، وما التفكير الجانبي إلا جزء من التفكير الإبداعي. وتثكل مخرجات التفكير الجانبي إبداعات أصيلة أحياناً، وأحياناً أخرى 


\section{مهارات التفكير الجانبى فى الرياضيات المناسبة لتلاميلذ الصف الثاني بـالمرحلة الاعدادية}

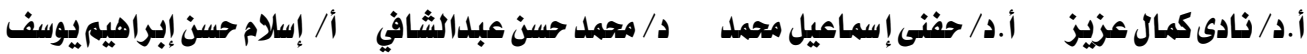

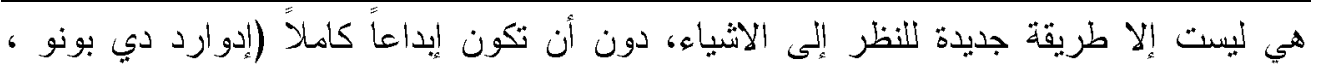

$$
\cdot(1+,+1)
$$

ويعتمد التفكير الجانبي على مساعدة المتعلم على التفتح العقلي، والاهتمام بجميع الأفكار ، وعدم

التسرع في إصدار الحكم بعدم جدوى بعض الأفكار، وتتُجيع المتعلم على الفضول الفكري وحب الاستطلاع، و الترحيب بتفاعل المعلومات معاً بدلاً من تخزينها في العقل في قو الب جامدة، والبحث عن الإجابات غير المألوفة، والتي قد تخالف تفكير الأغلبية، والاهتمام بطريقة تعامل المتعلم مع المشكلة ومدى مرونة تفكيره، و إطلاق العنان للتفكير ، وعدم الوقوف عند حد معين (إيمان حسين

$$
\text { محمد عصفور ، (1)V ، Y. (1). }
$$

ويهدف التفكير الجانبي إلى تغيير القو الب الفكرية الثثبتة، وإعادة بنائها من جديد، فذلك الثبات من شأند أن يجعل من العقل مجرد نظام تذكر تلقائي للقو الب الفكرية المصوغة مسبقا، أما التفكير الجانبي فيعمل على تقويض الأفكار القديمة التي تجاوزها الزمن، و إعادة بناء كل ما تم تعلمه من معلومات التفكير وأساليبه؛ لذا فهدفه القضاء على نظام التقولب الفكري، وجعل القو الب الفكرية في حالة دينامية حتى تقود أفكار المتعلم معرفته المستقلية (إدو ارد دي بونو ال مب ، ـ-V) .

ويسعي التفكير الجانبي إلى تغيير الأفكار التقليدية والمفاهيم والمدركات؛ لتوليد مفاهيم ومدركات جديدة قابلة للنطبيق في المجالات التي تحتاج إلى تفكير، و الأعمال التي تثوم بها ما لم يمكن أن تتم بشكل روتيني، ويعتمد التفكير الجانبي على تخطي العو ائق التي تحد التفكير في إطار معين ثم العمل على حل المشكلة بطريقة مختلفة ربما، أو جانبيه، ونتز ايد فرص النجاح في حل 


\section{مهارات التفكير الجانبى فى الرياضيات المناسبة لتلاميذ الصف الثاني بالمرحلة الاعدادية}

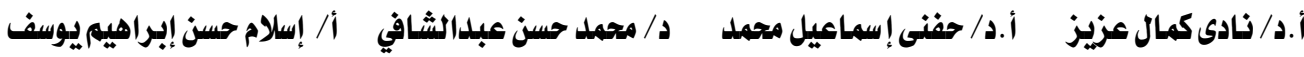

المشكلات مع تقلص العوائق الداخلية في عقولنا، و التي يطلق عليها في بعض الأحيان المعوقات

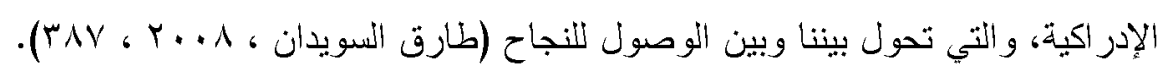

وممارسة المتعلم مهاز ات التفكير الجانبي تتمي العقل باتجاه التفكير الموسع، وجعل المتعلم يفكر خارج حدود التفكير التقليدي، ويو اجه المشكلات بأفكار أفضل؛ للحصول على نتائج جديدة، ويصدم طرقا لحل مشكلات مطروحة، ويطور أفكارًا جديدة، ويعمل على تطوير عادات وممارسات إبداعية، ويعمل على تحويل المشكلات إلى فرص للإبداع (وجيد المرسى أبولبن ، $\cdot(Y \cdot-Y)_{6}, Y \cdot 14$

\section{مشكثة البحث :}

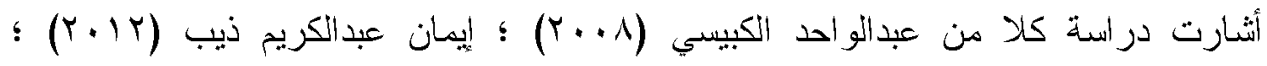

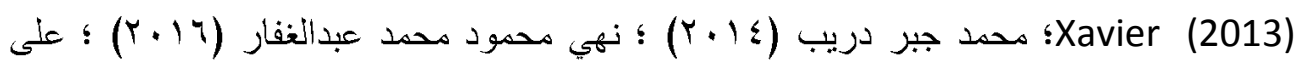

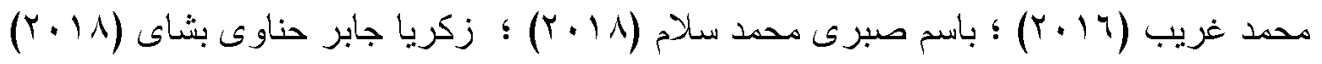
إلّى إدخال مبادئ ومهار ات التفكير الجانبي ضمن مناهج التعليم العام ابتداءً من رياض الأطفال ، مع تدريب المعلمين على استخدام التفكير الجانبي في عروضهم التدريسية، والأشطة الصفية، و اللاصفية ؛ لغرض تتميته لدى التتلاميذ ، وضرورة احتواء المناهج الدراسية لمبادئ التفكير، وخاصة التفكير الجانبي لنتميته لدى التتلاميذ ، كما أوصت بضرورة إعادة صياغة محتوى الرياضيات للمرحلة الإعدادية بحيث يتضمن العديد من الأثشطة و المو اقف التعليمية والحياتية التى تساعد التلاميذ على ممارسة مهار ات التفكير العليا بصفة عامة ومهارات التفكير الجانبي بصفة 


\section{مهارات التفكير الجانبى فى الرياضيات المناسبة لتلاميلذ الصف الثاني بـالمرحلة الاعلادية}

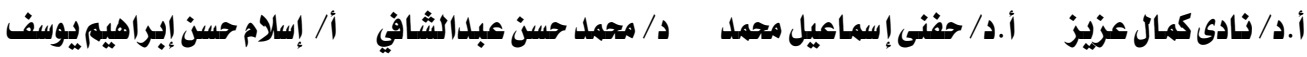

ومن ثم تحددت مشكلة البحث فى الحاجة الى تحديد مهار ات التفكير الجانبي فى الرياضيات

المناسبة لطلاب المرحة الإعدادية.

\section{أسئلة البحث:}

1- ما جوانب التعلم المتضمنة بوحدتى: العلاقة بين متغيرين و منوسطات المنلث بمقرر رياضيات الصف الثانى الإعدادى ج

ץ-ما مهار ات التقكير الجانبي فى الرياضيات المناسبة لتلاميذ الصف الثاني بالمرحلة الإعدادية؟

\section{أهداف البحث : 20}

1- تحديد فائدة بالمفاهيم و التععيمات و المهارات المتضمنة بوحدتى: العلاقة بين متغيرين و متوسطات المثلث بمقرر رياضيات الصف الثانى الإعدادى .

ץ- تحديد قائمة بمهار ات التفكير الجانبي فى الرياضيات المناسبة لتتلاميذ الصف الثاني بالمرحلة الإعدادية . الإنالية

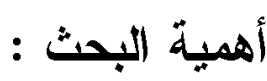

تقديم قائمة بالمفاهيم و التعميمات والمهار ات المتضمنة برياضيات الصف الثانى الإعدادي يمكن

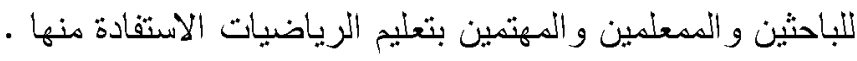

تقديم قائمة بمهارات التقكير الجانبي فى الرياضيات المناسبة لتلاميذ الصف الثانى الإعدادي بمكن

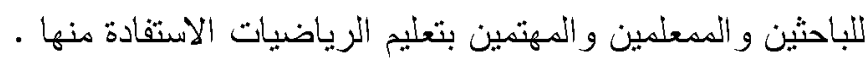

\section{محدداث البحث: :}

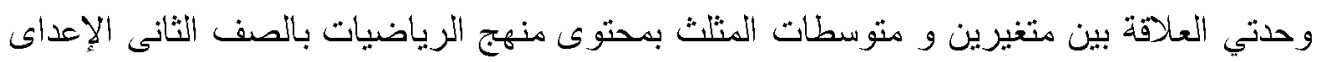

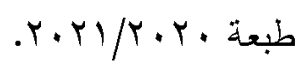

مهار ات التفكير الجانبي فى الرياضيات ( توليد إدر اكات جديدة - توليد هفاهيم جديدة - توليد أفكار جديدة - توليد بداثل جديدة - توليد إبداعات جديدة ) . 


\section{مهارات التفكير الجانبى فى الرياضيات المناسبة لتلاميلذ الصف الثاني بـالمرحلة الاعلادية}

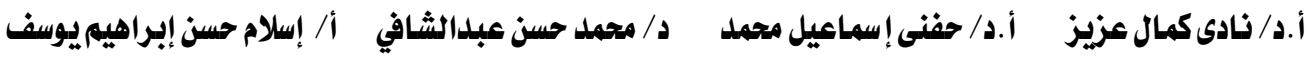

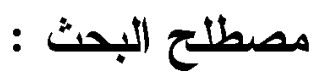

Lateral thinking : مهارات التفكير الجانبي

يعرف التفكير الجانبي بأنه : طريقة مبدعة تخيلية في حل المشكلات؛ تؤدي إلى تغيير

تصور ات المتعلم ومفاهيمه عن مشكلة ما (De Bono 1998, 3).

ويعرف أيضاً بأنه : نمط من التفكير يعتد على ابتكار أكبر قدر مدكن من الحلول و البدائل،

ويمكن من خلاله النظر إلى أكثر من جهة في المشكلة أو الموقف والقفز بخطوات حل المشكلة، أبي

الإبقاء على كل المعلومات المتاحة، ولا يعتمد في خطو اتثه على المسار الو اضح كما هو في التفكير

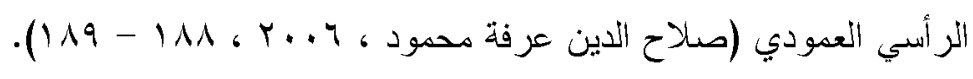

ويعرف إجرائياً بأنه : نثاط عقلي يقوم به التلميذ عند تعرضد لمشكلة رياضية، يمارس فيها الههارات العقلية المتثلة في: توليد مفاهيم جديدة، توليد أفكار جديدة، توليد بداثل جديدة، توليد إدراكات جديدة، توليد إبداعات جديدة بصورة تظهر فيها قدراته على إنتاج أفكار، وحلول غير تقليدية وغبر مكررة للشكلة الرياضية، والبحث في اتجاهات متعددة بدلاً من السير في اتجاه واحد.

\section{منهج البحث:}

تم استخدام المنهج الوصفي وذلك عند وصف تحليل محتوى وحدتى العلاقة بين متغيرين و متوسطات المثلث بكتاب الرياضيات الصف الثانى الإعدادي وتحديد مهارات التفكير الجانبي المناسبة لتلاميذ الصف الثانى الإعدادي • 


\section{مهارات التفكير الجانبى فى الرياضيات المناسبة لتلاميلذ الصف الثاني بـالمرحلة الاعلادية}

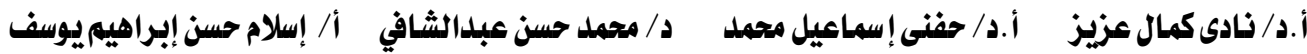

قائمة بالمفاهيم و التعميمات والمهار ات المتضمنة بوحدتى: العلاقة بين متغيرين و متوسطات المثلث بكتاب الرياضيات الصف الثانى الإعدادي . بهن

قائمة بمهار ات التفكير الجانبي فى الرياضيات المناسبة لتلاميذ الصف الثانى الإعدادي .

\section{خطواث البحث :}

للاججابة عن أسئلة البحث ستتبع الخطوات الإجرائية الآتية :

- - إعداد إطار نظري من خلال دراسة الأدبيات والدراسات السابقة ونوصيات المؤتمرات التي تتاولت: تحليل المحتوى ، ومهار ات التفكير الجانبي فى الرياضيات . - تحليل محتوى وحدتي : " العلاقة بين متغبرين " ، ومتوسطات المثلث " المقررتين على تلاميذ الصف الثاني الإعدادي في مقرر الرياضيات؛ لاستخلاص المفاهيم و التعميمات والمهارات، ثم عرضد على مجموعة من العسادة المحكمين المتخصصين في مناهج وطرق تعليم الرياضيات، وموجهي المرحلة الإعدادية؛ لحساب ثابته، و إجراءات

$$
\text { التعديلات الضرورية. }
$$

- إعداد قائمة بمهارات التنكير الجانبي في الرياضيات المناسبة لتلاميذ الصف الثاني الإعدادي وذلك في ضوء آراء مجمو عة من السادة المحكمين من المتخصصين في مناهج وطرق تعليم الرياضيات، وحساب الوزن النسبي لكل مهارة في ضوء آر ائهم. - - جمع البيانات و إجر اء المعالجات الإحصائية، و التوصل لنتائج البحث، وتحليلها وتفسير ها. - تقديم توصيات ومقترحات في ضوء نتائج البحث. 


\section{مهارات التفكير الجانبى فى الرياضيات المناسبة لتلاميلذ الصف الثاني بـالمرحلة الاعلادية}

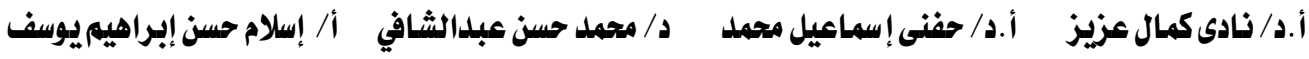

الخلفية النظرية للبحث :

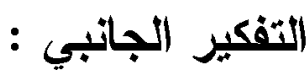

تعد تتمية مهار ات التفكير بعامة ، و التفكير الجانبي بصفة خاصدة لدى التلاميذ أحد أهداف تعليم

وتعلم الرياضيات فى جميع المر احل التعليمية ؛ لأنها تساعدهم على تعلم ما تحتويه الرياضيات من حقائق ومفاهيم ومهاز ات و اكتثاف معارف جديدة وتتمية العقل باتجاه التفكير الموسع ، وتكوين معنى للرياضيات عن طريق ربطها بالحياة .

\section{ماهية التفكير الجانبي :}

تعد عملية تنمية التفكير من الأولويات المهمة التى تقع على عاتق التعليم بصورة عامة ، فالتفكير الجانبى تفكير فى نسق غير تقليدي أو نمطي ، وغير مقيد بروتين أو طريقة محددة ، ويعمل على صقل مواهب التلاميذ وقدر اتهم ، وخلق بيئة تربوية فعالة ونثطة ( باسم صبرى

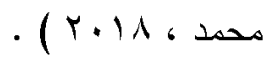

ولقد تعددت تعريفات مهار ات التفكير الجانبي من قبل التربويين ، ومن تلك التعريفات ما يلى:

تلك المهارات المرتبطة بإنتاج أكبر عدد من الأفكار الإبداعية والنظر إلى المشكلة من جهات مختلفة غير منطقية ، وتتمثل فى توليد إدر اكات جديدة ، وتوليد مفاهيم جديدة ، وتوليد أفكار جديدة ، وتوليد بدائل جديدة ، وتوليد إبداعات جديدة أصيلة ( إدوارد دي بونو ، ه . . ، كب ) .

الخروج عن المألوف فى التفكير والبحث عن طرق أخرى غير اعتبادية للوصول إلى الحل.)

(Sloane , 2006, 98 


\section{مهارات التفكير الجانبى فى الرياضيات المناسبة لتلاميلذ الصف الثاني بـالمرحلة الاعلادية}

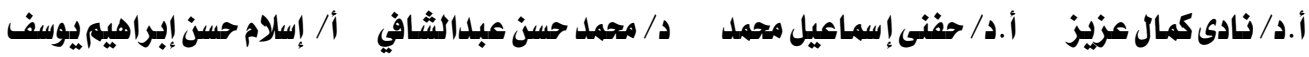

رؤية جديدة للإبداع بدون ثقيد لطرح الأفكار ، سواء من حيث المهارات الإبداعية أو مهئ

الاستر اتيجيات المستخدمة لتحقيق المهارات ، فهو نمط إبداعى موحد ومتكامل بيداعد الفرد على

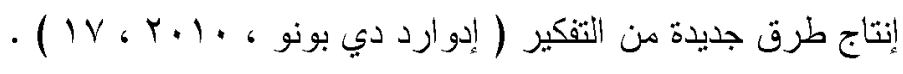

تفكير شامل يؤدى إلىى ابتكار الأشياء ، و ايجاد الحلول للمو اقف الغامضة ، و الابتعاد عن النمطية المعتادة ، وممارسة المتعلم لمهارات التفكير الجانبى تجعله يفكر خارج حدود التفكير التقليدي ، ويواجه المشكلات بأفكار إبداعية للوصول إلى نتائج فورية ، وييتكر طرقا لحل المشكلات ، ويطور أفكار ا جديدة وعادات وممارسات إيداعية ( إدو ارد دي بونو ، ، (ب ، 9 ) )

نمط من أنماط التفكير بعتمد على ابتكار أكبر عدد من الحلول و البدائل لمشكلة أو موقف من المواقف الحياتية ، ويتميز بالبحث والانطلاق بحرية فى اتجاهات متعددة ، ويركز على توليد الطرق الجديدة لرؤية الأثياء ، ومن مسمياته التفكير الجوانبي ( الاحاطي ) والابداع الجاد

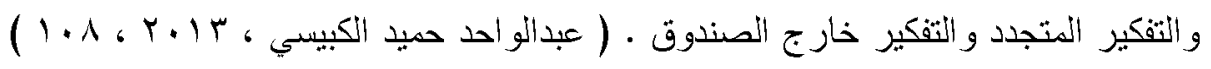
تفكير يجعل المتعلم يفكر خارج حدود التفكير التقلبدي ، ويواجه المشكلات بأفكار أفضل للحصول على نتائج فورية ، ويصمم طرقا لحل المشكلات الرياضية ، ويطور أفكار جديدة ، ويسعى إلى تغيير الأفكار و المفاهيم و المدركات ، نتوليد مفاهيم ومدركات جديدة قابلة للتطبيق (

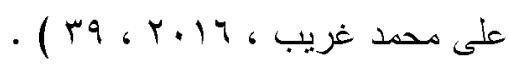

موقف عقلى بمكن المتعلم من البحث عن البدائل أو الحلول لحل المشكلات ومواجهة المو اقف بطرق غير تقليدية من خلال التتقل بين الأفكار بطرق جانبية ( إحاطية ) ولنيس رأسية نمطية ، 


\section{مهارات التفكير الجانبى فى الرياضيات المناسبة لتلاميذ الصف الثاني بالمرحلة الاعدادية}

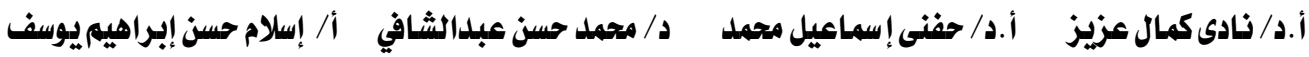

وبذلك فهو يهتم بإعادة بناء الأفكار ونوظيفها للوصول إلى حلول ابداعية ( إيمان حسنين محمد ، إدمئ

$$
\cdot\left(r_{0}, r+1\right)
$$

أحد أنو اع التفكير غير التقليدي ، يتتع به الثخص صاحب الملكة الإبداعية الذى يحاول دائما

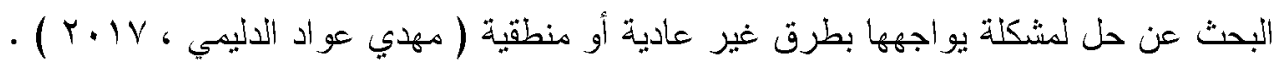

نمط من التفكير لا يعتد على المسار الواضح ، و إنما على ابتكار أكبر عدد من الحلول و البدائل غير المألوفة ويمن النظر من خلاله على أكثر من جهة فى المشكلة أو الموقف ( باسم

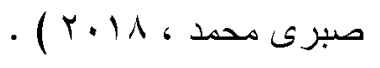

أحد أنماط التفكير الذى يعتمد فيه المتعلم على التتأل وروية المشكلة الرياضية بطرق وأبعاد مثعددة ، باحثا عن طرق جديدة للحل ، أو الوصول إلى بداثل وأفكار وحلول إبداعية ، دون الثقيد بمسار معين ( زكريا جابر حناوي ، 11 إب ، 00 ) .

مجموعة السلوكيات التى تمكن التّلاميذ من التعامل مع المو اقف الحياتية والعملية بصورة غير تقليدية وتتمثل فى توليد إدر اكات جديدة ، وتوليد مفاهيم جديدة ، وتوليد بدائل جديدة ، وتوليد أفكار

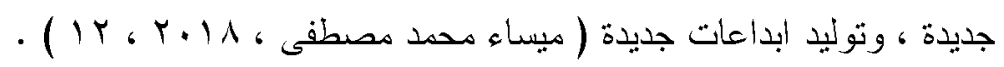
مما سبق ومن خلال استعر اض مفاهيم مهار ات التفكير الجانبي امكن تعريفها فى البحث الحالى بأنها : هو نثاط عقلي يقوم به التلميذ عند تعرضد لمشكلة رياضية ، يمارس فيها المهار ات العقلية المتمثلة في: توليد مفاهيم جديدة ، توليد أفكار جديدة ، توليد بدائل جديدة ، توليد إدر اكات جديدة ، 


\section{مهارات التفكير الجانبى فى الرياضيات المناسبة لتلاميلذ الصف الثاني بـالمرحلة الاعدادية}

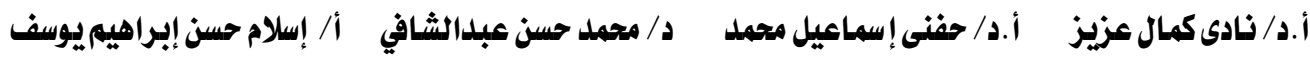
توليد إيداعات جديدة بصورة نظهر فيها قدراته على إنتاج أفكار ، وحلول غير تقليدية وغير مكررة للمشكة الرياضبة ، و البحث في اتجاهات متعددة بدلاً من السبر في اتجاهو واحد .

\section{مهار ات التفكير الجانبي :}

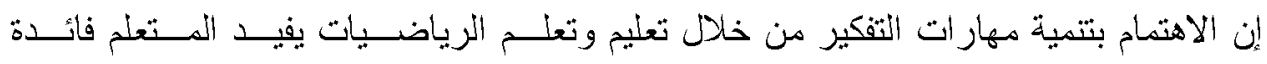
دائمة تبقى فى سلوكه فقد يتعلم التلميذ من خلال استتناجه لـبعض القو أعـد الرياضــية أنسـاليبا متتوعة لحل المشكلة وطرقا متعددة في التفكير العلمي الصــحيح وتـــر العــنوات وفـــ ينسـى التلميذ هذه القو اعد و القو انين وييقى فى ســلوكياته العلميــة و الحياتيــة مهــار ات حـل المشــكلة ومهارات التفكير ، وهذا لا يتأتى بتعليم وتعلم الرياضيات من خــلال الحفـظ لكـن يـأتي مسن خلال المشاركة النشطة القائمة على الكثير من جهد المـتعلم و التوجيــهـ والإرشـاد مــن جانـبـ المعلم ( العزب محمد زهران ، 11 أب ، 170 ) .

وحيث أن ممارسة المـتعلم لمهـار ات التفكيــر بصــفة عامــة و التقكيــر الجـانبي بصــفة

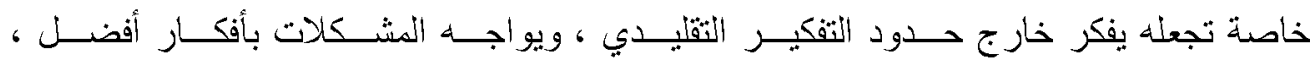
ويولد فكرة ما من خــلال أفكــار أخــرى ، ويصــم طرقــا لحـل المشـكلات المطروحسـة ، ويطور أفكار ا جديدة ـ ويعمل علـى تطــوير عـادات وممارســات إبداعيـة ، ويعمل على

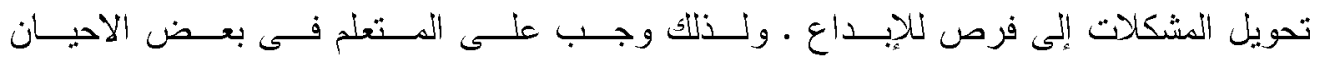
الخروج عن المـألوف فى التفكير والبحث عن طرق أخرى غيــر اعتياديــة للوصــول للحـل . ( Sloane, 2006, 98) 


\section{مهارات التفكير الجانبى فى الرياضيات المناسبة لتلاميلذ الصف الثاني بـالمرحلة الاعلادية}

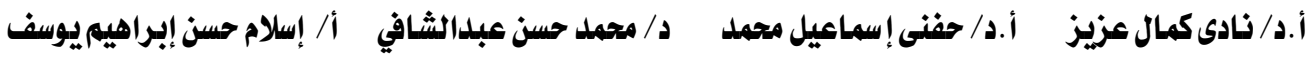

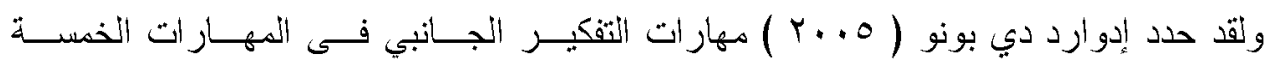

أ) توليد إدراكات جديدة Generation of new Perception

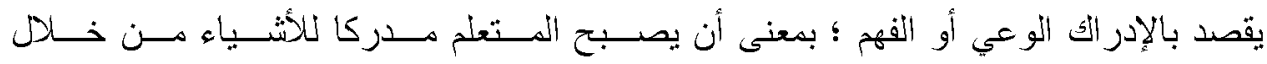

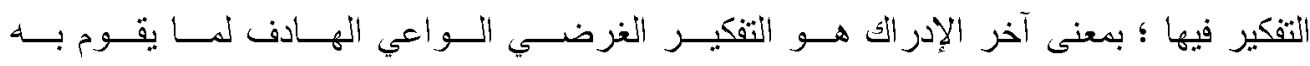

المتعلم من عمليات ( عقلية ) ذهنية بغرض الفهـم ، أو اتخــاذ القــراز ، أو حـل المشـكلات ،

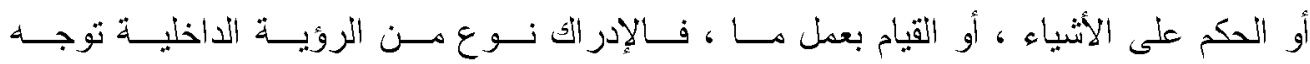

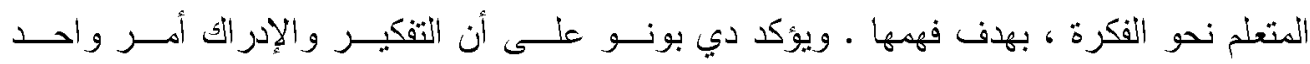

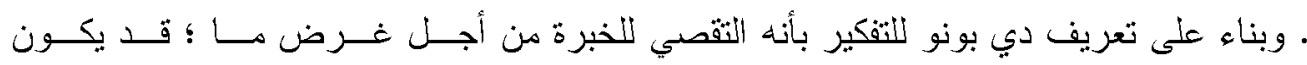
هذا الغرض تحقيق الفهم ، أو اتخاذ القزرار ، أو حل المشكلات ، أو القيام بعمل ما .

ب) توليب مفاهيم جليدة Generation of new Concepts

يشير دي بونو إلىى أن المفاهيم هي أسـاليب أو طرق عامـــة لعهـل الأثـــياء ، ويعبـر عـنـ المفاهيم أحيانا بطرق غير واضحة ، وحتى يعبر عن مفهـوم مـــا ، لا بـــــــن بــل مجهـود لاستخلاص هذا المفهوم ، وثمة ثلاثة أنواع من المفاهيم هي:

- مفاهيم غرضية أو ذات هدف : وهي تتعلق بما يحاول المتعلم أن يحققه .

- مفاهيم آلية : حيث تصف مقدار الأثر الذى سينتج عن عمل ما . - مفاهيم القيمة : وتتشير إلى الكيفية التي يكتسب العمل من خلالها قيمته . 


\section{مهارات التفكير الجانبى فى الرياضيات المناسبة لتلاميلذ الصف الثاني بـالمرحلة الاعدادية}

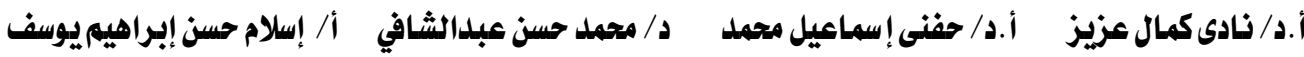

ج) توليد أفكار جليدة Generation of new Ideas

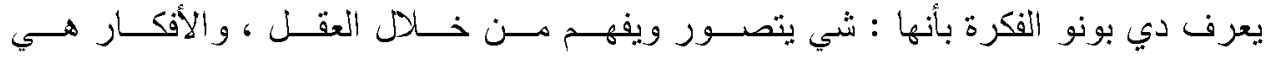
طرق مادية لتطبيق المفاهيم ، و الفكرة يجــب أن تكــون محـددة ، ويجــب أن نوضــع الفكــرة

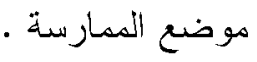

ومن أجل توليد أفكار جديدة بحذر دب بونــو مـن الــرفض النــريع والفـوري للأفكــار ؛ ويثير إلى أن الرفض السريع للأفكار يأتى مــن القيــود التــي فرضــت علـى العقـل ، فـإذا كانت الفكرة لا تتو افق مع هذه القيود فإنها تتجه نحو الرفض ، وهــذا هــو الاســتخدام المبكـر

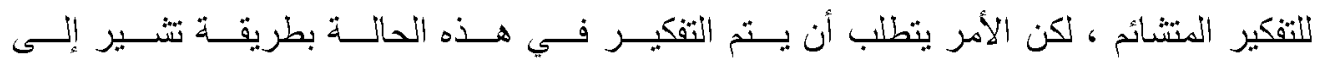

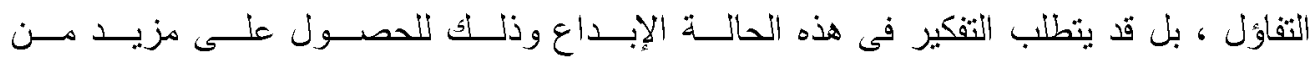

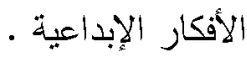

د) توليد بائل جديدة Generation of new Alternatives

من مبادئ التفكير الجانبي أنه طريقة خاصدة لتأمسل الحــول مــن بـين مجموعـة ممكنــة ومتاحة ، حيث يهتم التفكيـر الجـانبي باكتثــان أو توليــد طــرق أخـرى لإعـادة وتتظـيم المعلومات المتاحة ، وتوليد حلول جديدة بدلا مــن الســير فـى خـــ مسـتقيم ، والـــي يقـود عندئذ إلّى تطوير نمط واحد ، وأن البحث عـن طــرق بديلـــة أمسـر طبيعـي لــدى المتعلمـين الذين يشعرون أنهم يقومون بذلك ، وهذا أمر صحيح إلى حد مــا ، لكـن البحــث مـن خـلال التفكير الجانبي يذهب إلى ما هو أبعد من البحث الطبيعي فقى البحـث الطبيعـي عـن البــدائل يبحث المتعلمون عن أفضل البدائل الممكنة ، لكن فى البحث عن البــائل مــن خـلاد التفكيـر 


\section{مهارات التفكير الجانبى فى الرياضيات المناسبة لتلاميذ الصف الثاني بالمرحلة الاعدادية}

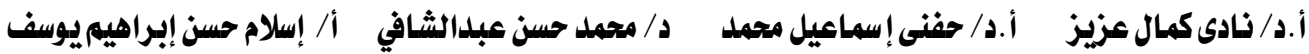

الجانبي يتيح للمنعلمين توليد بدائل كثيرة بحسب قـدرتهم ، ولا ييحـث التفكيــر الجـانبي عـن أفضل البدائل ولكن عن البداثل المتعددة فقـى البحــث الطبيعـي عـن البــائل يهـتم الهـتعلم بالبدائل المنطقية ، بينما فى التفكير الجانبي ليس من الضروري أن نكون البداثل منطقية.

\section{هـ) توليد إبداعات جديدة Generation of new Innovations}

يؤكد دي بونو أن الابداع هو العمل على إنثاء شئ جديد ، بــلالامسن تحليـل حـدث قـديم

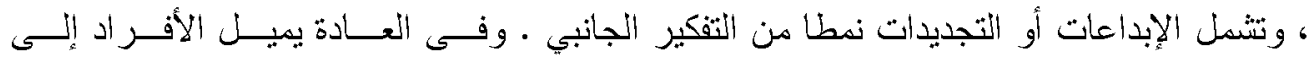
انتاج الاستجابات الأكثر أصـالة من خلال الاســتمرار فـى العهـل علـى المهـــة التعليميـة أو

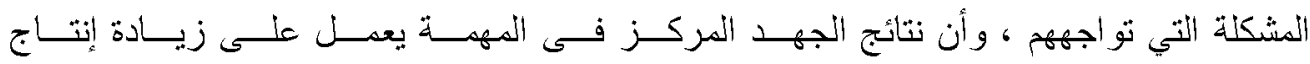

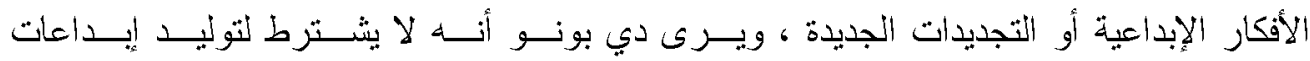
جديدة أن يتصف الفرد بمستوى عال من الذكاء إنما يحتاج الإبـــاع إلـى درجـة بسـبطة مـن

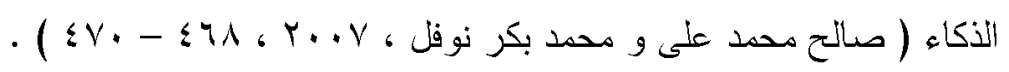

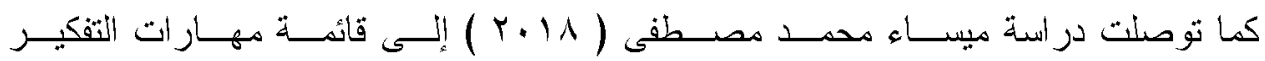

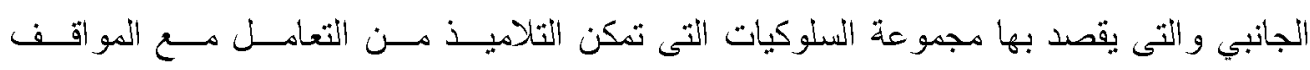
الحياتية و العملية بصورة غير تقليدية وهي كالتالي : 1) توليّ ادراكات جديدة : وتعنى قدرة المتعلم على - التعرف على العبار ات و الأفكار الو اردة بالموقف و التعبير عنها ـ - ترجمة العبارات والأفكار لصور أخرى . 


\section{مهارات التفكير الجانبى فى الرياضيات المناسبة لتلاميل الصف الثاني بـالمرحلة الاعدادية}

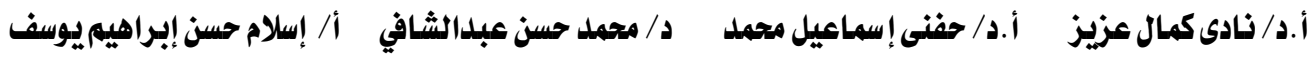

با توليخ مفاهيم جديدة : وتعنى قدرة المتعلم على

- توضيح الموقف و اكثثاف العلاقات بين عناصره .

- التوصل إلى تفسير مناسب للموقف .

r) تمليد بدائل جديدة : وتعنى قدرة المتعلم على

- أستخدام مفردات و ألفاظ مناسبة للموقف .

$$
\text { - وصف العلاقات و الأفكار - }
$$

؛) توليب أفكار جليدة : وتعنى قدرة المتعلم على

- عرض وتقديم أفكار غير تقلبدية مناسبة للموقف .

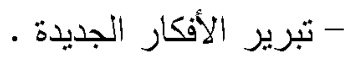

ه) توليث ابداعات جديدة : وتعنى قدرة المتعلم على

- التعبير عن الأفكار غير المألوفة .

- التمبيز بين الأفكار الواردة بالموقف .

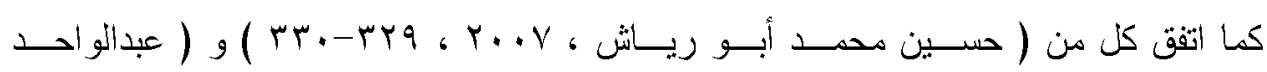

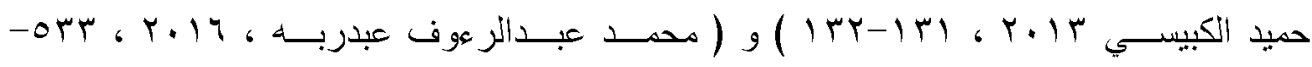

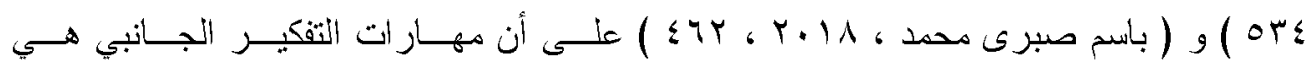

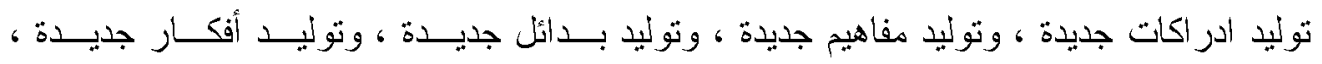

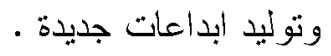




\section{مهارات التفكير الجانبى فى الرياضيات المناسبة لتلاميلذ الصف الثاني بـالمرحلة الاعدادية}

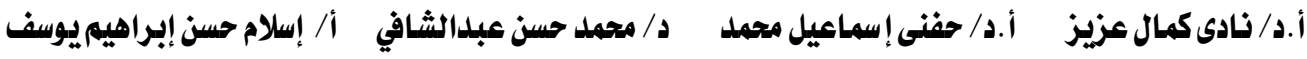

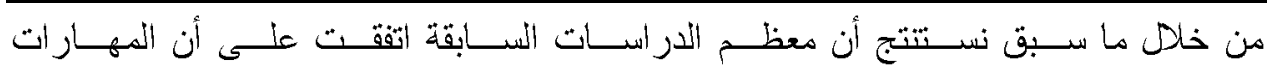

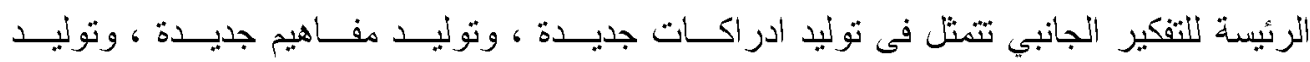

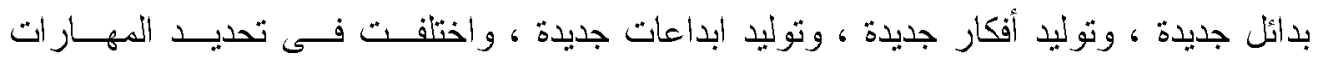
الفر عية المنبتقة من كل مهارة رئيسة ، وقد حددها الباحسـ كمــا هــو متضــمن فــى القائمسـة النهائية .

\section{إعداد مواد البحث:}

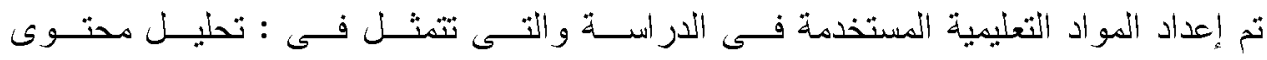
موضو عات وحدتى : " العلاقة بـين متغيــرين " ، ومتوســطات المنتــث " بمقـرر رياضــيات

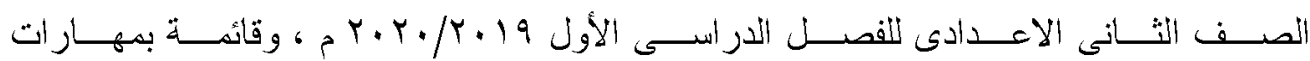

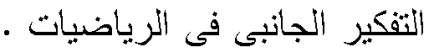

أولا : تحليل محتوى وحتى : " العلاقة بين متفيرين ، ومتوسطات المثلث "

يهدف تحليل المحتـوى إلــى تحديــــ المفــاهيم و التعميــات و المهـــار ات المتضـــنة فـى

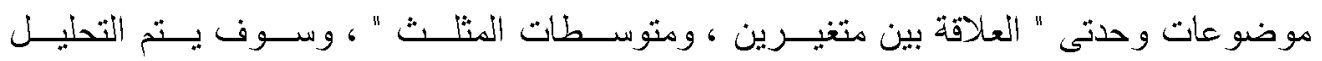
فى ضوء التعريفات التالية :

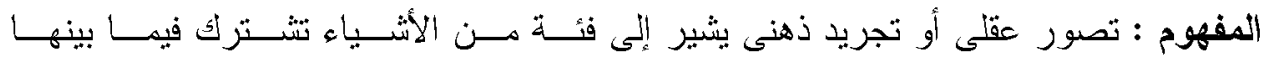
فى خاصية أو أكثر فى وحسـتى " العلاقــة بــين متغيــرين ، ومتوســات المثلــث " بمقـرر الرياضيات للصف الثنانى الاعدادى . 


\section{مهارات التفكير الجانبى فى الرياضيات المناسبة لتلاميذ الصف الثاني بالمرحلة الاعدادية}

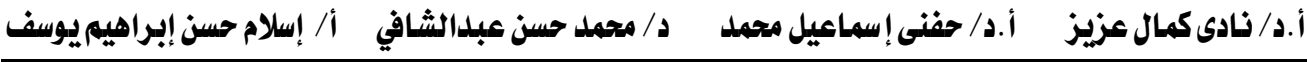

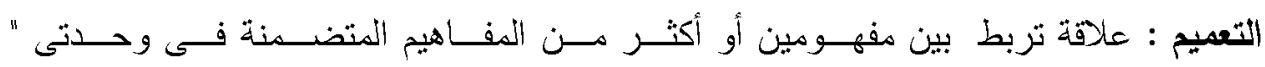

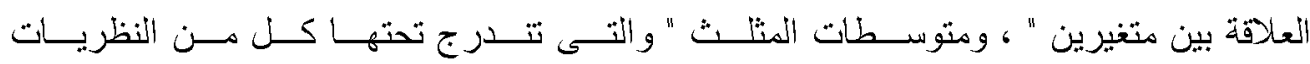
و النتائج و القو انين و المسلمات و الحقائق و القو اعد.

المهارة : هى الكفاءة فى أداء العمليات الرياضية المتضــنة فـى وحسـتى " العلاقـة بـين متغيرين " ، ومتوسطات المثنث " بفهم ودقة وسر عة سو اء أكان ذلك أداء يدويا أو عقليا.

تم تحليل الوحدتين إلى جوانب الـتـعلم (المفــاهيم ، و التعميهـات ، و المهــار ات) ، ولتحديــد مدى صدق التحليل: تم عـرض نتــائج تحليـل الوحسـتين على مجموعـة مــن المحكــين المتخصصين فى المنــاهج وطـرق تـدريس الرياضــيات ومــوجهى الرياضـيات بالمرحلــة

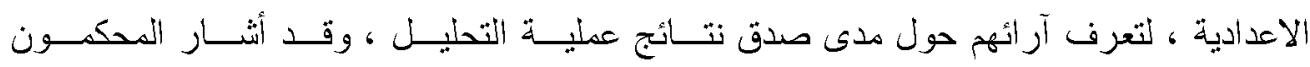

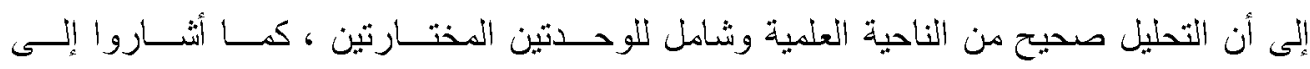

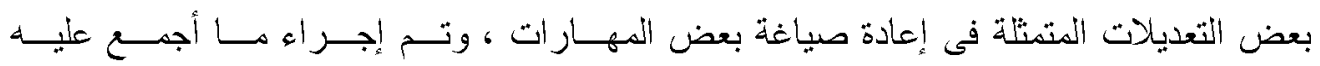
المحكمون من تعديلات ، و عد ذلك دلالة صدق التحليل ، ملحق (r) . ثانيا : بناء قائمة مهارات التفكير الجانبى

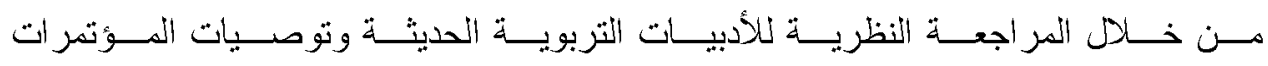

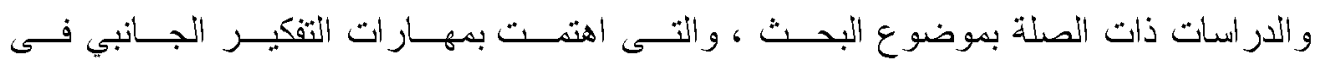
الزرياضيات ، أمكن تحديد قائمة بمهار ات التفكيــر الجـانبي فـى الرياضـيات اثــتملت علـى خمسة مهار ات رئيسة انبتقت إلى تسعة و عشرين مهارة فرعية . 


\section{مهارات التفكير الجانبى فى الرياضيات المناسبة لتلاميلذ الصف الثاني بـالمرحلة الاعلادية}

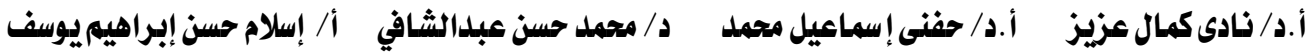

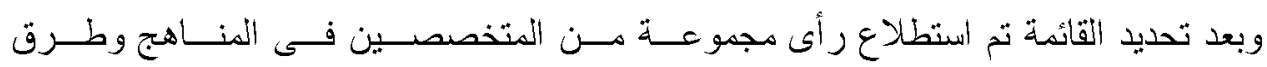

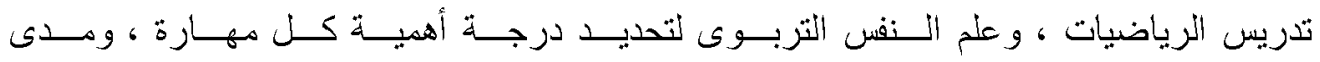

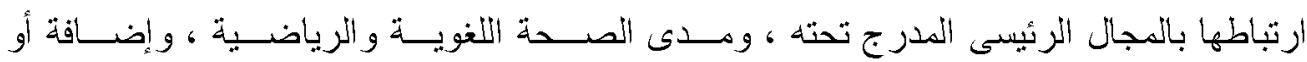
حذف أو تعديل بعض المهار ات ، ملحق (r) .

\section{نتائج البحث وتفسيرها :}

أولا : سعى البحث إلّى الإجابة عن السؤ ال الذى ينص على " ما جو انب التعلم المتضدنة بوحدتى: العلاقة بين متغيرين و متوسطات المثلث بمقرر رياضيات الصف الثانى الإعدادى ؟ "

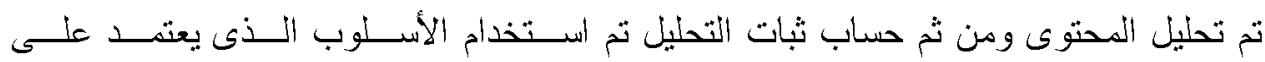
فيام الفرد نفسه بإجر اء عملية التحليل على فترتين زمنيتـين متباعـدتين ( فــارق زمنـى شـــر

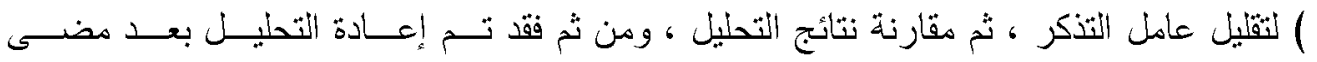

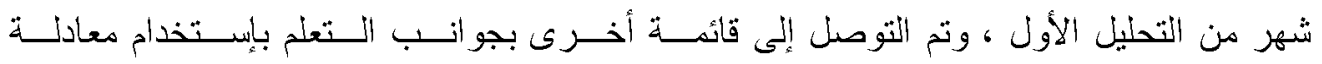

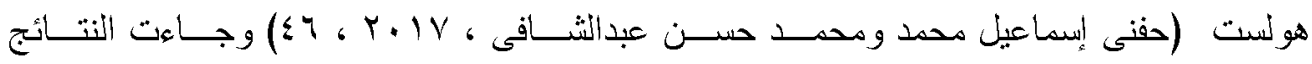

كما هو موضح بجدول (1) (1)

\begin{tabular}{|c|c|c|c|c|}
\hline قيمة معامل & عدد مرات & المرة الثانية & المرة الاولى & هرات التحيل \\
\hline$\% 97$ & ir & 15 & ir & المفاهيم \\
\hline$\% 90$ & rq & $r T$ & rq & التعميمات \\
\hline$\% 9 \wedge .7$ & r & $r v$ & r & المهارات \\
\hline$\% 94.0$ & & & & معاهل ثبات \\
\hline & & & & ليل \\
\hline
\end{tabular}


مهارات التفكير الجانبى فى الرياضيات المناسبة لتلاميذ الصف الثاني بـالمرحلة الاعدادية

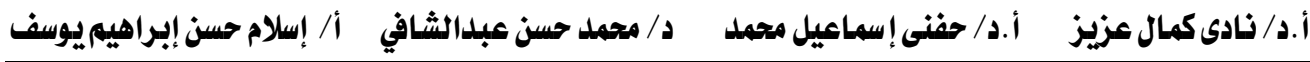

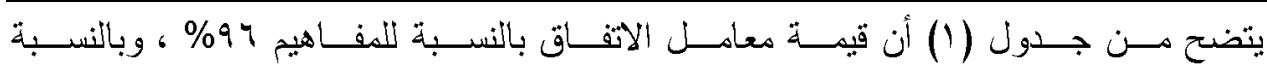

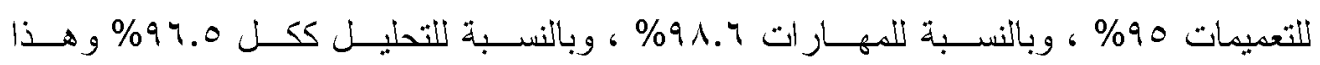
يدل على ثبات التحليل . وبعد التأكد من صدق وثبات التحليـلـل أصــبح تحليـلـ المحتـوى فـى صورته النهائية معدا للاستخدام كما هو بلمحق (r). وهذا يجيب على السؤال الأول للبحث : ما جو انب التعلم المتضمنة بوحدتى: العلاقة بين متغيرين و متوسطات المثلث بمقرر رياضيات الصف الثانى الإعدادى ؟ ثانيا :سعى البحث إلى الإجابة عن السؤال الذى ينص على " ما مهارات التفكير الجانبي فى الرياضيات المناسبة لتنلاميذ الصف الثاني بالمرحلة الإعدادية ؟ "

وقد تم حساب المتوسط الحسابى والوزن النسبى لكل مهــارة فرعيـة كمــا هــو موضــوح بجدول (r) (

المتوسطات الحسابية والأوزان النسبية لمهارات التفكير الجانبي برياضيات المرحلة الاعدادية

\begin{tabular}{|c|c|c|c|}
\hline المزبن & المترسط & المهارة الفزعية & الرئيسة \\
\hline$\% \wedge \cdot . \wedge$ & 1.7 & قزاءة عبارات المشكلة بأسلوبه الخاص & \multirow{3}{*}{ توليب إدراكات } \\
\hline$\% \wedge \leqslant .7$ & $1 . V$ & التعبير عن العبارات والأفكار الواردة بالمشكلة & \\
\hline$\% \wedge \wedge . \diamond$ & 1.1 & تزجمة المشكلة فى صور جديدة & \\
\hline
\end{tabular}


مهارات التفكير الجانبى فى الرياضيات المناسبة لتلاميذ الصف الثاني بالمرحلة الاعدادية

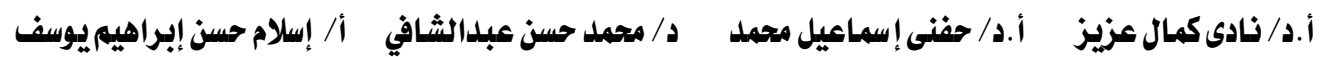

\begin{tabular}{|c|c|c|c|}
\hline التوزن النسبى & 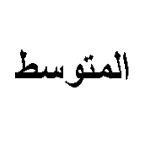 & المهارة الفزعية & 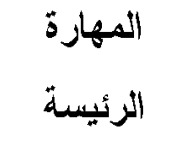 \\
\hline$\% 1 \ldots$ & $r$ & توليخ تصورات جديدة & \\
\hline$\% 94 . r$ & 1.9 & تزجمة العبارت والأفكار لصور أخرى & \\
\hline$\% \wedge \wedge .0$ & 1.1 & التعبير عن الأفكار و العلاقات بصيغ جديدة & \\
\hline$\% \wedge \varepsilon . ५$ & $1 . v$ & قراعة المفاهيم التواردة بالمثكلة بأسلوبه الخاص & \multirow{7}{*}{ توليد مفاهيم } \\
\hline$\% \wedge . . \wedge$ & 1.7 & التعبير عن المفاهيم الواردة بالمشكلة بلغته الخاصة & \\
\hline$\% 1 \ldots$ & r & صياغة مفاهيم المشكنة فى صور جديدة & \\
\hline$\% \wedge . . \wedge$ & 1.7 & توليب مفاهيم علانقية جديدة متضدنة بالمشكنة & \\
\hline$\% a$ r.r & 1.1 & اشتقاق مفاهيم رياضية بديلة بناء على دراسة مفاهيم & \\
\hline$\% 94 . \mathrm{r}$ & 1.9 & تطبيق المفاهيم الجيدة التى توصل اليها حول & \\
\hline$\% \wedge \wedge . \diamond$ & 1.1 & تطبيق حالات جديدة تنطبق على المفاهيم التى تم & \\
\hline$\% \circ v . v$ & $1 . r$ & إعادة تقييم الأفكار الواردة بالمشكنة & \multirow{2}{*}{ توليب أفكار } \\
\hline$\% \wedge \wedge .0$ & 1.1 & التعبير عن الافكار الواردة بالمشكلة بأسلوبه الخاص & \\
\hline
\end{tabular}


مهارات التفكير الجانبى فى الرياضيات المناسبة لتلاميذ الصف الثاني بـالمرحلة الاعدادية

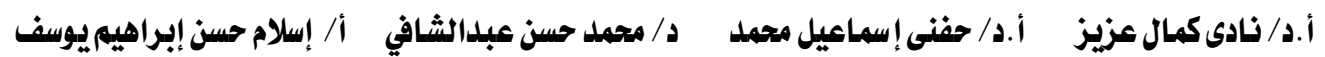

\begin{tabular}{|c|c|c|c|}
\hline المزن النسب & 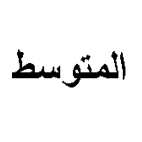 & المهارة الفرعية & المئيسة - المهارة \\
\hline$\% a r . r$ & 1.1 & تحليل المعلومات الواردة بالمشكنة لإستنتاج افكار & \\
\hline$\% 94$. r & 1.9 & انتاج أفكار جديدة طبقا للمفاهيم الجديدة التى توصل & \\
\hline$\% 1 \ldots$ & r & انتاج افكار جديدة وغير تقليدية مناسبة للمشكلة & \\
\hline$\% \wedge \cdot . \wedge$ & 1.7 & توليب معانى جديدة مرتبطه بالمشكلة المطروحة & \\
\hline$\% 1 \ldots$ & r & الوصول إلى حلول للمشكنة من خلال مسارات جيدة & \multirow{5}{*}{ توليد بدائل } \\
\hline$\% \wedge \wedge .0$ & 1.1 & استذدام مفردات و ألفاظ غير مكررة لحل المشكلة & \\
\hline$\% \wedge \leqslant .7$ & $1 . V$ & استبدال العلاقات والأفكار الثواردة بالمشكلة بعلاقات & \\
\hline$\% 94 . r$ & 1.9 & التوصل الى بدائل غير مألوفة & \\
\hline$\% 41.0$ & $1 . r$ & إعادة انتاج الطول بثكل مختلف & \\
\hline$\% \wedge \wedge . \diamond$ & 1.1 & إعادة صياغة حل المشكلة بصورة غير مألوفة & \multirow{3}{*}{ توليب إبداعات } \\
\hline$\% \wedge \cdot . \wedge$ & 1.7 & تنظيم حل المشكلة فى شكل جديد & \\
\hline$\% a r . r$ & 1.1 & انتاج حلول فريدة من خلال التفكير فى مسارات & \\
\hline
\end{tabular}


مهارات التفكير الجانبى فى الرياضيات المناسبة لتلاميذ الصف الثاني بـالمرحلة الاعدادية

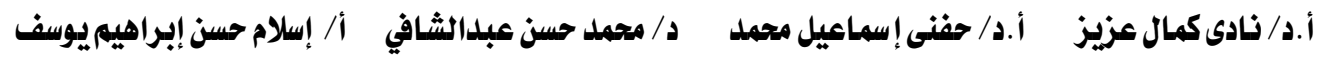

\begin{tabular}{|c|c|c|c|}
\hline التوزن & المتوسط & المهارة الفزعية & الرئيسة \\
\hline$\% \wedge \leqslant .7$ & $1 . v$ & التوصل الى حل غير مألوف للمشكنة & \\
\hline$\% 1 \ldots$ & r & تنويع الطول غير المألوفة المرتبطة بالمشكلة & \\
\hline
\end{tabular}

\%oV.V يتضح من جدول (Y) أن مهارات التفكير الجانبي قد حازت على أوزان نسبية ما بين إلى . . 1\% ، وبناء على الأوزان النسبية تم حذف المهار ات التى حصلت على وزن نسبى أقل من م و وعددها (Y) مهارة ، ليصبح عدد مهاز ات القائدة (YV) مهارة ، وبهذا أصبحت القائمة فى . صورتها النهائية معدة للاستخدام ملدق (r) . وهذا يجيب على السؤال الثاني للبحث : ما مهار ات التفكير الجانبي المناسبة لتلاميذ الصف الثاني بالمرحلة الإعدادية ؟

التوصنياث : (1)

- - - ضدرورة الاهتمام بتنمية مهار ات التفكير الجانبي لدى التلاميذ فى جميع المر احل التعليمية

- عقد دورات تدرييية لتنريب المعلمين قبل الخدمة وأثناء الخدمة على تتمية مهارات التفكير الجانبي وكيفية تتميتها لدى تلاميذهم.

- تطوير برامج إعداد معلمي الرياضيات بالمرحلة الاعدادية بكليات التربية لتصبح مقرر اتها مبنية على اساس التفكير الجانبي ورعايته وتتمبة مهاراته ، وإضافة مقررات تؤكد على أهمية المعلم المشجع على التفكير الجانبي • 


\section{مهارات التفكير الجانبى فى الرياضيات المناسبة لتلاميلذ الصف الثاني بـالمرحلة الاعلادية}

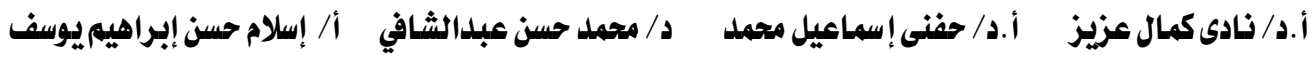

- ضرورة توفير بيئة تعليمية محفزة تساعد على تتمية مهار ات التفكير الجانبي لدى الطلاب

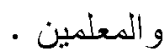

- تطوير مناهج الرياضيات بالمرحلة الاعدادية بما يسمح للمعلم والطالب من استخدام مهار ات التفكير الجانبي ، وتضمين أدلة المعلمين استراتيجيات واساليب تدريس تتسى التنكير الجانبي ومرتبطة بما يدرسد التنلاميذ. - - توجيه نظر القائمين على تطوير مناهج الرياضيات بتضمين مهار ات التفكير الجانبى فى مقررات الزياضيات بالمر احل التعليمية المختلفة

\section{البحوث المقترحة :}

- اجراء دراسة للكثف عن العوامل المؤثرة فى مهارات التفكير الجانبي لدى تلاميذ

$$
\text { المرحة الإعدادية . }
$$

- - برنامج تدريبي لتتمية مهار ات تدريس التفكير الجانبى لدى الطلاب المعلمين شعبة

$$
\text { الرياضيات بكلية التربية . }
$$

- فاعلية نموذج التعلم التوليدى فى تتمية مهارات التفكير الجانبى لدى تلاميذ المرحلة

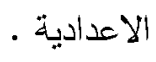

- تقييم الأداء التدريسي لمعلمى الرياضيات فى ضوء مهارات التفكير الجانبي بالمر احل

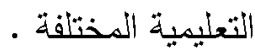
- استخدام مدخل حل المشكلات مفتوحة النهاية فى تتمية مهارات التقكير الجانبى لدى

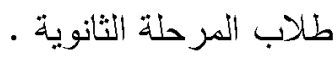


مهارات التفكير الجانبى فى الرياضيات المناسبة لتلاميذ الصف الثاني بالمرحلة الاعدادية

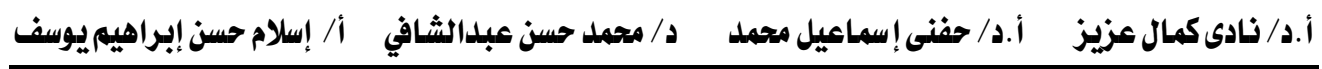

$$
\text { المر اجع }
$$

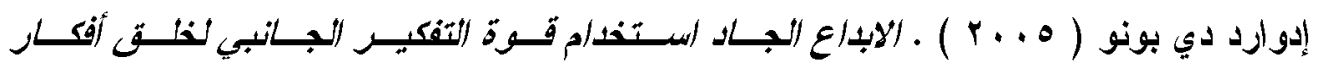

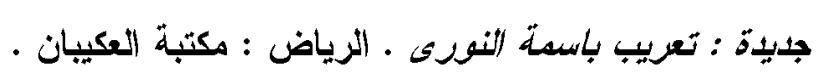

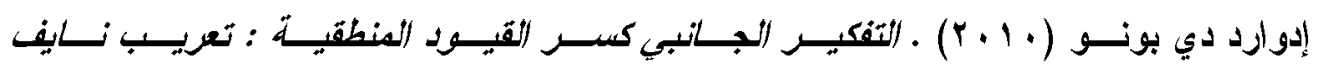
الخوص ، دمثث: الهيئة العامة السورية للكتاب.

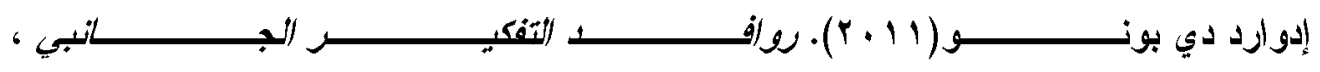
.www.debonoconsulting.com

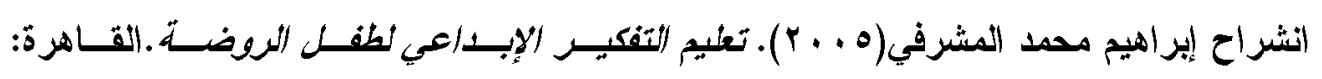
الارار المصرية اللبناتية.

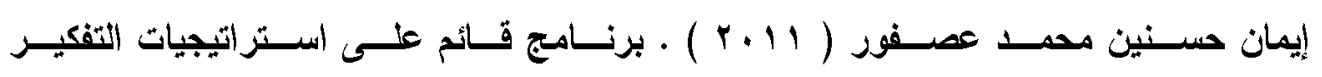

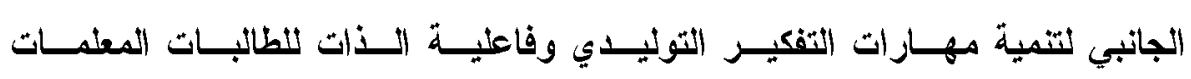

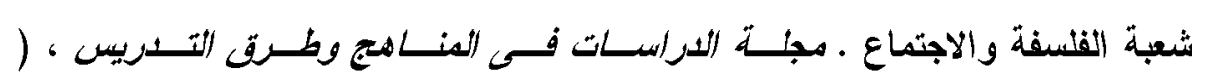

$$
\text { . ro- ir c ( IV }
$$

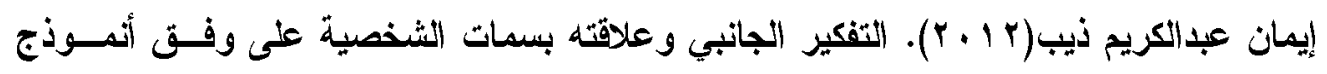

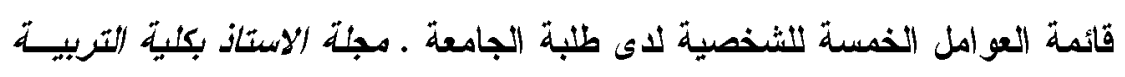

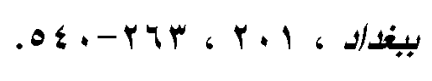

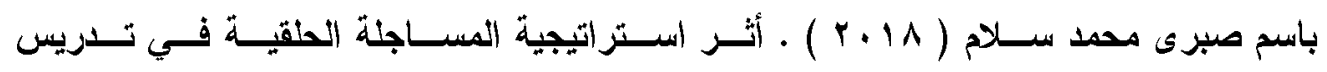

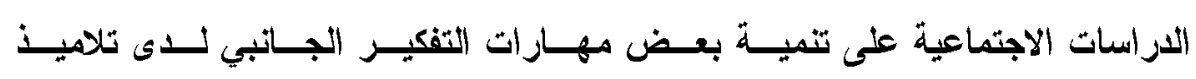

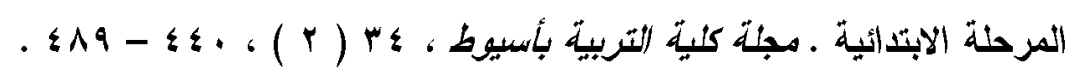

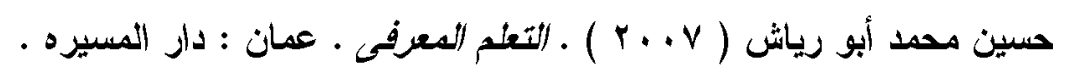


مهارات التفكير الجانبى فى الرياضيات المناسبة لتلاميذ الصف الثاني بـالمرحلة الاعدادية

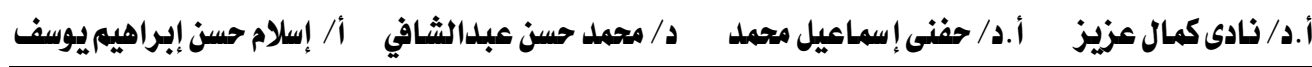

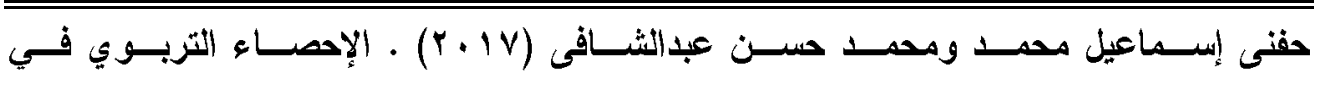

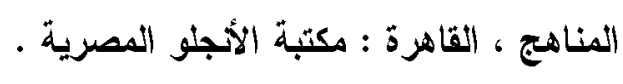

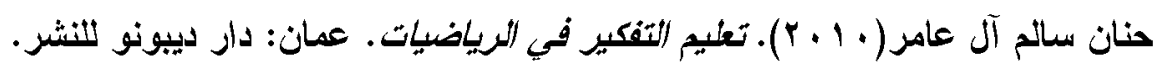

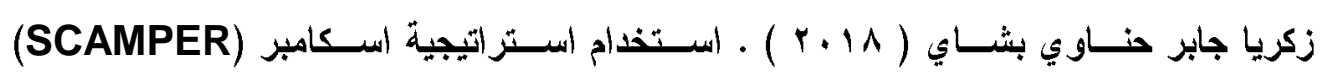

فى تدريس الهندسة لتنمية مهارات التفكير الجانبي واتغــاذ القــــرار الابــاعي لــدي

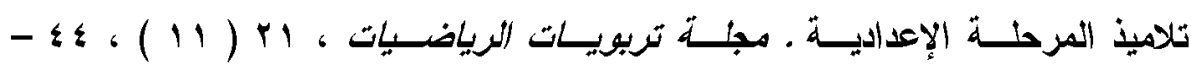

. 9 \&

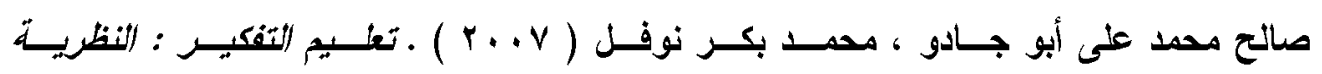

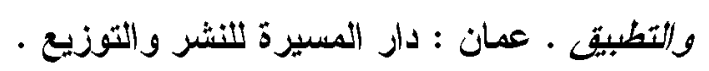

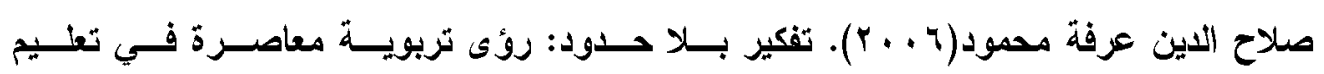
التفكير وتتلمه. القاهرة: عالم الكتب.

طارق السويدان(^ . . r). صناعة الابداع. الكويت: شركة الإبداع الفكري.

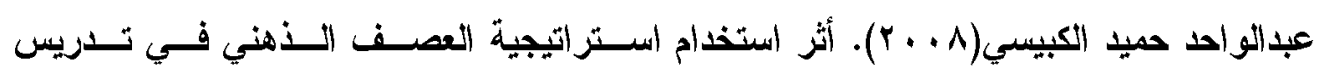
الرياضيات على التحصيل والتفكير الجانبي لدى طلاب الصف الثـاني المتوسـط ،

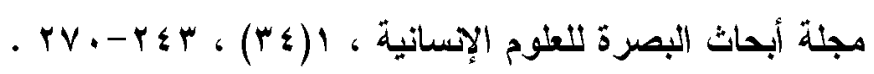

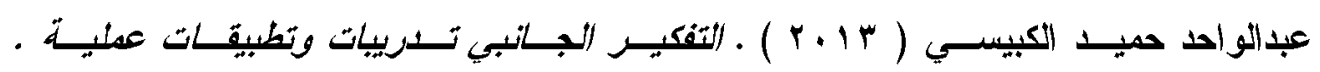
عمان : مركز ديبونو لتعليم التفكير · لـ

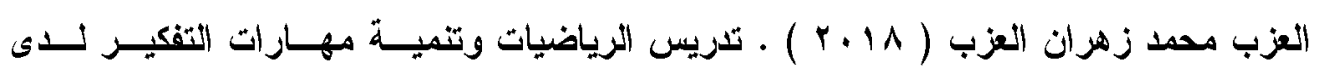

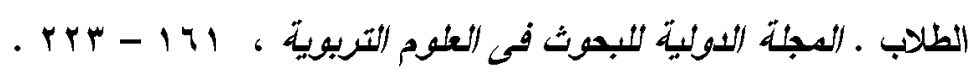




\section{ههارات التفكير الجانبى فى الرياضيات المناسبة لتلاميذ الصف الثاني بـالمرحلة الاعدادية}

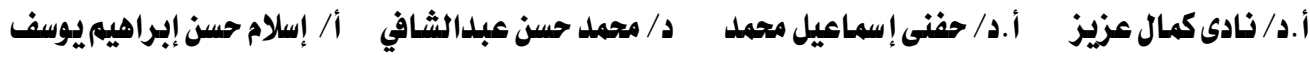

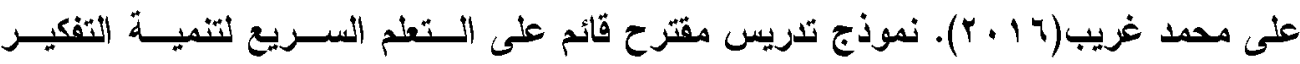
الجانبي و التنظيم الأنى في الرياضـيات لـــى تلاميــذ الصــف الثــني الاعـدادي ،

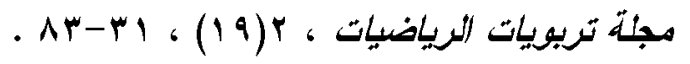

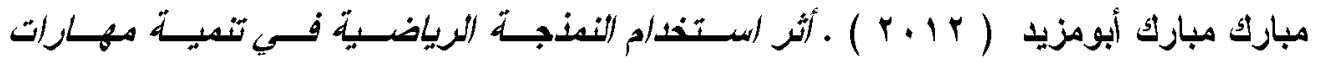
التفكير الإبداعي للى طلاب الصف الســادس الاساســي بدحافظـات غـزة ( رسـالة ماحستير ) ـ كلية التربية ، جامعة الازهز بغزة . محد جبر دريب(؛ 1 +r). التفكير الجانبي ومهارات حل المشكلات لدى طلبة المدارس المتميزين

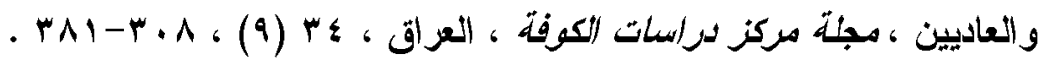

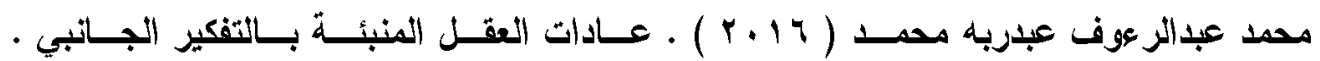

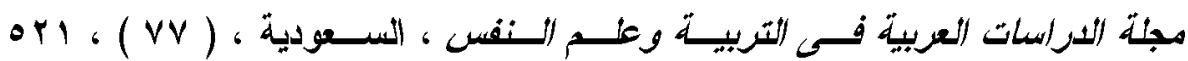

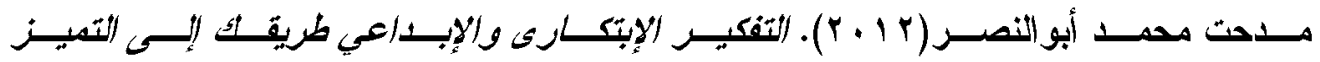
والنجاح. القاهرة: المجموعة العربية للتدريب والنشر.

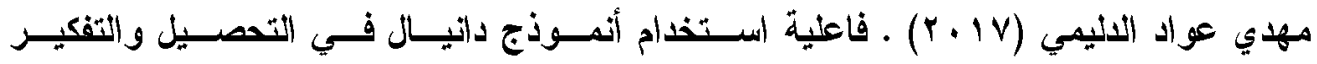
الجانبي لدى طلبة الصــف الثـاني المتوســط فــي مـــادة الرياضـيات فــي العـراق (رسالة ماجستير) • كلية العلوم التربوية ، جامعة آل البيت .

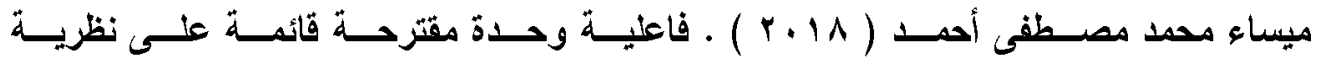

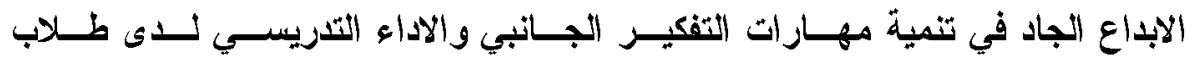

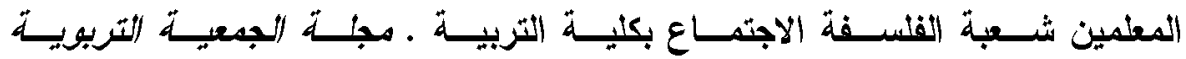

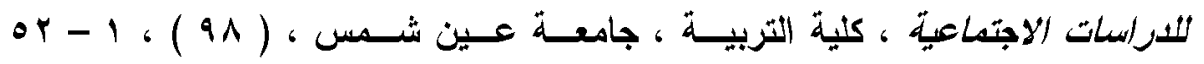


مهارات التفكير الجانبى فى الرياضيات المناسبة لتلاميذ الصف الثاني بالمرحلة الاعدادية

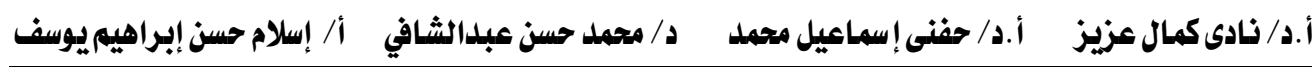

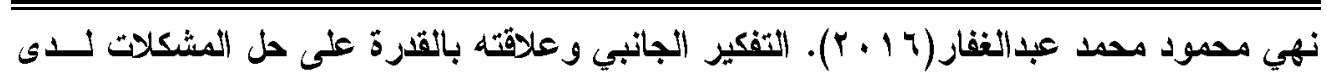

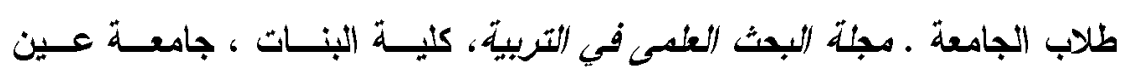

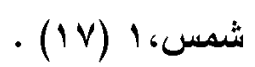

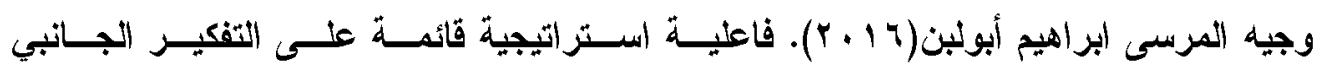

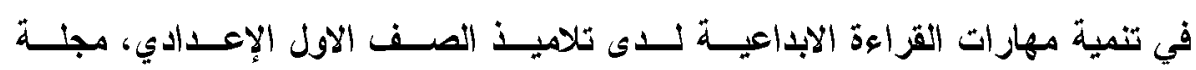

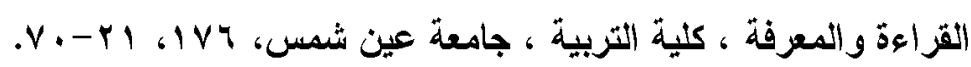

المراجع الأجنبية : المر

De Bono ,E (1998). Lateral thinking concepts, New York, Harper \& Row Publishers.

Sloane (2006). The leaders guide to lateral thinking skill , sterling publishing Co. Inc. , New York.

Lawrence;A and Xavier;A . (2013) . Lateral thinking of prospective teachers , Light House, Journal of Educational Reflection, Vol.1:NO.1 . 